\title{
Review and Prospect of Research on Interrogative Modal Particles of Unearthed and Handed-down Literature of the Warring States
}

\author{
Weiming Peng \\ College of Liberal Arts \\ South China Normal University \\ Guangzhou, China 510006
}

\author{
Jianya Zhang \\ College of Liberal Arts \\ South China Normal University \\ Guangzhou, China 510006
}

\begin{abstract}
In order to carry out systematic description and analysis of the situation of Chinese interrogative modal particles in the Warring States, the author takes the unearthed literature of the Warring States as the basic corpus, and uses the handed-down literature of the Warring States as the circumstantial evidence corpus to make the study. And the author tries to sort out two problems. First, this paper explains the basis of selecting linguistic data for unearthed and handeddown documents in warring states period. Second, this paper makes the reflection on the definition of interrogative modal particles in Chinese grammar. Thirdly, it reviews the progress of the study on unearthed and handed-down Chinese interrogative modal particles in the warring states.
\end{abstract}

Keywords-unearthed literature; handed-down literature; Chinese in warring states period; interrogative modal particles; review

\section{INTRODUCTION}

What's Corpus Selection of Unearthed and Handed-down Literature of the Warring States? At present, the scholars who have studied unearthed words and grammar of the Warring States, such as He Linyi [1] and Zhang Yujin [2], advocate the classification of characters of the Warring States according to the different materials of written literature, namely: bronze text, bamboo and wooden slips characters, silk text, lacquerware characters, stone characters, currency characters, royal seal characters and pottery characters. We believe that Chinese of the Warring States is synchronic language in the late period of ancient Chinese. When analyzing its linguistic features and grammatical features, it is necessary to divide the unearthed literature of the Warring States into five kinds of literature according to the location of the unearthed literature and ancient writing materials, namely, literature of Qin Dynasty, literature of Chu Dynasty (including literature of Zeng nation), literature of Zhao, Wei and Han dynasties, literature in Qilu region and literature of Yan Dynasty with regional characteristics.

In order to avoid the complicated and infinite discussion on the problems of the age, the authors and the spread of handed-down literature, the so-called handed-down literature corpus of the Warring States has basically referred to the concept of "the basic corpus of the Warring States" proposed by Hua Jianguang and the corresponding literature, including: "Zuo Zhuan", "Guo Yu", "The Analects of Confucius", "Mozi", "Yanzi", "Mencius", "Zhuangzi", "Xunzi", "Han Feizi", "Mister Lv's Spring and Autumn Annals" and "Strategies of the Warring States" [3]. However, we believe that "basic corpus of the handed-down literature of the Warring States" proposed by Hua Jianguang still has limitations. Hua ignores the corpus value of the verses of the handed-down literature of the Warring States. The linguistic laws reflected in the verses (the literature of the Warring States influenced by the rules and forms of classical poetic composition) are not necessarily the spoken language at the time. However, it still has very important reference value. There is obvious difference among two books of "Laozi" and "The Songs of Chu" and other handed-down documents of the Warring States. The most obvious difference is that "Laozi" and "The Songs of Chu" are verses, and other corpus is prose. Compared with prose, verses must have special grammatical order and unique grammatical features. Therefore, when we make conclusions based on the corpus of "Laozi" and "The Songs of Chu", we must pay attention to the particularity of style. If certain language phenomenon is only found in "Laozi" and "The Songs of Chu", this grammar does not exist in other literary corpus. It is likely to reflect the grammatical features of the verses of the Warring States. Therefore, we believe that the verse documents such as "Laozi" and "The Songs of Chu" can also be used as corpus of the handed-down literature of the Warring States.

\section{INTERROGATIVE MODAL PARTICLES}

Before we understand the Chinese interrogative modal particle, we should establish the consensus. There is no much difference in the use of modal particles between ancient and modern Chinese. Qi Huyang divides the tone of modern Chinese into two categories, namely, functional tone and will tone. Functional tone includes indicative mood, interrogative tone, imperative tone and exclamatory tone. Will tones include potential mood, willing tone, tolerance tone, etc. [4] Qi Huyang's research pointed out that the modal particle at the end of the sentence expressed functional tone. And the modal particle in modern Chinese has little difference from the modal particle in ancient Chinese. 
The so-called interrogative modal particle refers to the vocabulary used to express the interrogative tone at the end of the interrogative sentence. In addition, some scholars have suggested that whether there is a questioning modal particle at the end of the sentence can also determine the displacement of the sentence component. For example, Lu Jianming and Shen Yang pointed out in the "Study on Chinese" that there were two ways to construct interrogative sentences in various languages in the world. First, if there is no modal particle at the end of the sentence, it must be shifted by composition. Second, if there are modal particles at the end of the sentence, there is no need for component displacement [5].

"Chinese interrogative sentences do not need to move any components; there are interrogative modal particles at the end of the Chinese sentence". "There is no modal particle at the end of the sentence. And it must rely on the component displacement" (Lu Jianming, Shen Yang). We need to discuss these views whether Chinese is established or not.

In modern spoken Chinese, "Are you going to Shanghai?" (你去上海?) And "Will you go to Shanghai?" (你去 上海吗?) The first sentence is a case that there is no question word. It is a sentence that directly occurring question through the interrogative tone. And the latter sentence adds the modal particle "吗" (ma) on the basis of the preceding sentence to indicate the question. The modal particle "吗" (ma) is used to mark the interrogative sentence and belongs to the end of the sentence. Some of the ideas or theories of interrogative modal words in modern Chinese may not be suitable for studying the interrogative modal particles in Chinese unearthed and handed-down literature of the Warring States.

Then, what are the interrogative words in the unearthed and handed-down literature of the Warring States? There are following two types of literature: unearthed literature and handed-down literature. And the author would review various viewpoints.

\section{REVIEW OF THE INTERROGATIVE MODAL PARTICLES IN UNEARTHED LITERATURE OF THE W ARRING STATES}

Zhang Yujin pointed out that modal particles played a role in enhancing the amount of information expressed in tone [2]. There are two kinds of grammatical features of modal particles.

The first is usually used at the end of a sentence, and can also be used in the middle of the sentence. The former is called the modal particle at the end of the sentence, and the latter is called the modal particle in the middle of the sentence.

The second is to express the specific intention with the tone of sentence, but also to enhance the amount of information expressed in the tone. The modal particles in the unearthed literature of the Warring States are divided into: (1) Declarative modal particles. (2) Interrogative modal particles. (3) Exclamation modal particles.

There are two interrogative modal particles: "hu" (乎), "yu" (与). In a word, "hu" (乎) is a modal particle that expresses true question. And "yu" (与) is a modal particle that expresses the uncertainty.

Zhang Yujin also pointed out that the interrogative modal particles included "hu" (乎), "yu" (与), "yi" (抑), "zhi" (执), etc. in the unearthed literature of pre-Qin Dynasty. Among them, "yi" (抑) and "zhi" (执) only appeared in inscriptions on bones or tortoise shells of the Shang Dynasty. And they are all modal particles that express true doubts. The exclamation modal particle "hu" (乎) which could produce interrogative "hu" (乎) expresses the exclamation [6].

Why does the interrogative modal particle "hu" (乎) produce exclamation modal particle "hu" (乎)? Zhang Yujin draws on the views of scholars such as Shi Yuzhi and Qi Huyang on the rules of modern Chinese grammar. He believes that the exclamation modal particle "ma" (吗) that can be developed from the interrogative "ma" (吗) of modern Chinese can be confirmed [2]. There are studies on the exclamation modal particle "ma" (嘛) that can be developed from the interrogative "ma" (吗) of modern Chinese. Shi Yuzhi believes that in modern Chinese, "ma" (吗) is a modal particle that expresses doubts. In addition, there is a exclamation modal particle "ma" (嘛). Therefore, in terms of expression function, distribution and phonetic form, it can be proved that the exclamation modal particle "ma" (嘛) is developed from the interrogative "ma" (吗) [7]. Qi Huyang also believes that the most basic semanteme of modern Chinese "ne" (呢) is the interrogative tone, which leads to the tone of the counterquestion. And the exclamation word is derived from the counterquestion word [4]. Viewing from "ma" (吗) and "ne" (呢), the "hu" (乎) of ancient Chinese can also be developed from the counterquestion word "hu" (乎) to the exclamation word "hu" (乎).

The "hu" (乎) at the end of the interrogative sentence contains the "hu" (乎) used alone and "hu" (乎) used with "ye" (也). It can express the interrogative tone and the interrogative tone is stronger. It is a true interrogative word. According to Zhang Yujin's analysis, in the unearthed literature of the Warring States, the modal particle "hu" (乎) at the end of the sentence mainly express interrogative tone, which can be used alone or in combination with "ye" (也) [6].

However, according to the published unearthed corpus of the Warring States, we believe that it is necessary to supplement Zhang Yujin's conclusion. The interrogative modal particle "hu" (乎) at the end of the sentence can be followed by the words such as "而已" (eryi), "才（哉）"(cai, zai), "鸣" (wu) and so on.

Also, the author would introduce a dubious modal particle "yu" (与). Zhang Yujin believes that the modal particle "yu" (与) only appears 22 times in the unearthed literature of the Warring States. According to these cases, it can be seen that the modal particle "yu" (与) in the unearthed literature of the Warring States is not used in exclamatory sentences, but only used in non-question sentences, special questions, choice questions and rhetorical questions [6]. The book discusses in detail the problem of using interrogative modal particles in conjunction with other modal particles in the unearthed literature of pre-Qin dynasty. According to the 
unearthed literature, we would get the conclusion. In the Chinese of pre-Qin dynasty, when these two modal particles are used together, the interrogative modal particles are usually placed before the exclamatory modal words. The modal particles used in the same way bear the task of expressing tone. However, the emphasis of tone falls on the last modal particle; and the last modal particle determines the sentence category [2]. In addition, Zhang Yujin also mentions that "ye" ( 也) is used in conjunction with interrogative modal particles. At this time, "ye" (也) is always placed before the interrogative modal particle [6].

In addition, the author also sees some dissertations on the interrogative words or modal particles or of the unearthed literature of the Warring States. For example, there are two innovations in Zhang Zhenzhen's "modal particle in the unearthed literature of the Warring States".[8] First, the author has collected scholars' research results on modal particles in the unearthed literature of the Warring States. Second, the author explores the diversity, regionality, development and evolution of these forms of modal words. In Cheng Wenwen's "Modal Particles of Silk Medical Book", the modal particles include "也"(ye), "矣"(yi), "焉" (yan), "耳 "(er), "乎"(hu), "邪"(ye), "夫"(fu),"哉"(zai), "殹"(yi). The modal particles "乎"(hu) and "邪"(ye) are mainly used in interrogative sentences to express interrogative tone. The function of "也"(ye) is the most comprehensive, and it also expresses judgments, statements and interrogative tone. Its vitality is strong [9].

Finally, we can also see some papers on the modal particles of the unearthed or handed-down Chinese of preQin dynasty in a certain period, such as Zhang Zhenlin's "modal particle in the ancient writing materials of pre-Qin dynasty" [10], Chen Yongzheng's "modal particle in the bronze inscriptions of Western Chou and the Spring and Autumn period", etc. [11] They are masterpieces on the modal particle of the unearthed literature of pre-Qin dynasty.

\section{A REVIEW OF THE RESEARCH ON INTERROGATIVE MODAL PARTICLES IN THE WARRING STATES}

There are some of the controversial words used in the academic circles at the end of the interrogative sentence.

Wang $\mathrm{Li}$ believes that in ancient Chinese, the interrogative modal particles which are used alone include " 乎"(hu), "诸"(zhu), "与（欵） (yu)", "邪"(ye), "耶"(ye), "哉 "(zai), "为"(wei). [12] Zhang Yujin also points out that in the handed-down documents of the Warring States Period, the modal particles at the end of the interrogative sentence include four words such as "乎"(hu),"与"(yu), "其"(qi), "而 "(er).

The author also introduces the modal particle "乎"(hu) at the end of the interrogative sentence. Zhang Yujin believes that the "乎"(hu) at the end of the interrogative sentence (including the one used alone and the one is used in conjunction with "ye, 也") can express interrogative tone. The interrogative tone is stronger. It is a true interrogative tone of speech. And Zhang Yujin points out that in the handed-down literature, "乎"(hu) can also express the exclamation tone; this usage comes from the usage of the interrogative tone [6].

The author makes the discussion on the usage of the modal particle "yu"(与) at the end of a sentence. Wang Li believes that the word "yu"(与) does not generally mean pure doubts except for being used in the specific interrogation and alternative interrogations [12]. In most cases, the use of "yu"(与) is what the speaker conjects. It is not convinced, asking the interlocutor to confirm. Guo Xiliang's views are similar to Wang Li's views. From the tone of the expression of "yu"(与), Wang Kezhong also points out that it can be divided into four categories: alternative question, rhetorical question, probe question, right and wrong question. And in the rhetorical question, it also has exclamation tone [13]. He Leshi points out that there are two main uses of "yu"(与): (1) interrogative modal particles. (2) Exclamation modal particles [14]. When it is used as an interrogative modal particle, it can be used at the end of the interrogative sentence and alternative interrogation to express the interrogative tone. When it is used at the end of the rhetorical sentence, it expresses the rhetorical mood. When it is used at the end of the measure question, it indicates the measure interrogative tone.

The author introduces modal particles at the end of the interrogative sentence such as "乎 (hu) $1 /$ 与(yu)/耶(ye)". Hua Jianguang believes that tone belongs to a broad concept, including modality and illocutionary force. The modality includes the attitude of prior knowledge and prioritization, while the illocutionary force refers to statements, doubts, imperatives, exclamation, etc. [3]. Hua Jianguang also points out that the modal particle at the end of the sentence mainly expresses the doubtful modality and adjustment, and all belong to the broad category of "modality" [3]. In a word, (1) "也 (ye)/矣 (yi)/已 (yi)/耳 (er)/夫 (fu)" are modal particles. (2) The most basic function of "乎 (hu) $1 /$ 与 (yu)/耶 (ye)" is to express the "unbelievable" modality of the speaker, which is a interrogative modal particle. Among them, "乎 (hu) 1 " is more used for questioning (counterquestion), "与 (yu)/耶 (ye)" ( = 也乎 (ye, hu) 1) are more used for speculation (proof). However, the use of the above modal particles in a sentence is specifically questioning or speculation, it needs to be combined with specific context to analyze. Regarding the grammatical meaning of "与 (yu)/耶(ye)", Hua Jianguang proposes that "与(yu)/耶(ye)" is equal to "ye + hu" (也+乎) [3]. Zhang Yujin points out that in most scholars' views, two modal particles are used together, and each expresses the specific tone. However, the focus of the tone falls on the last modal particle. And the last modal particle determines the sentence category of the entire sentence. If "与 (yu)/耶(ye)" is equal to "ye + hu" (也+乎), the tone of "与(yu)/耶(ye)" should be a combination of confirming tone and questioning tone, and not a speculative tone [2]. Therefore, Hua Jianguang's view that "与 (yu)/耶 (ye)" is equal to "ye + hu" (也十乎) is likely to be discussed.

There is the discussion on whether the modal particle "焉 yan (安, an)" at the end of the sentence indicating the question. Hong Bo [15] and Zhang Yujin [6] believe that the modal particle "焉 yan (安, an)" at the end of the sentence is affirmative. At the same time, it has the meaning of 
expressing the situation. The modal particle "焉 yan (安, an)" is basically the same as the "雨" (er). These two words are sometimes used together. According to the unearthed literature, "焉 yan (安, an)" only appears in the declarative sentence. And it is a statement modal particle, which does not indicate the tone of doubt, measurement, exclamation, etc. Even if "焉 yan (安, an)" appears at the end of the interrogative sentence, the measurement sentence, and the exclamatory sentence, it does not express doubts, measures, exclamation, etc. It still expresses its original meaning.

Regarding the nature of the "wei" (为) at the end of the interrogative sentence (specifically, we are discussing the nature of "wei" (为) at the end of the sentence "何以...为" (why...), Zhu Yunshen believes that the "wei" (为) at the end of the sentence is used as a verb "doing"(做). And "he"(何) is an interrogative pronoun, acting as an object of "wei" (为) [16]. Xu Futing also analyzes this sentence. Xu Futing has made a conclusion. First, in the sentence "何以...为" (why..), the "wei" (为) is main verb. Second, the "he"(何) is the adverbial of the verb. Third, the "wei" (为) is a questioning modal particle [17]. He Leshi and Xu Futing have the same viewpoint. They also believe that in the handed-down literature, "wei" (为) can be used as a modal particle, expressing the tone of question, rhetorical question, exclamation, etc. [14] Zhang Yujin agrees Zhu Yunshen's view that "wei" (为) is a verb, and analyzes the interrogative sentence "何以麻为"(why) and the answer "以为衣" in the unearthed literature of the Warring States. Among them, "wei" (为) in "何以为"(why) is the preposition. "wei" (为) is the verb. "he"(何) is the preposition object of the verb "为" [2].

Regarding the nature of "者"(zhe) (that is, the "谓+者" wei+zhe) at the end of the interrogative sentence, Wei Peiquan regards "者"(zhe) as "demonstrative pronoun" in "Zuo Chuan - twenty-eight years of Xiang Gong 's period", "Who dares?" [18]. Fang Youguo believes that "者"(zhe) is a transferred referent pronoun [19]. He Leshi thinks that "者 "(zhe) is a questioning modal particle at the end of the interrogative sentence or the rhetorical question. The common question words "who", "孰"(shu), "he"(何) and "an" (安) would be in the sentence, which can be translated as "ma"(吗), "a" (啊), etc. [14] Zhang Yujin disagrees with He Leshi's view or Fang's view that "者"(zhe) is regarded as a transferred referent pronoun. First, taking the sentence of "who + weizhe(谓者)" as an example, it can be transformed into "weizhe(谓者), sheiye(谁也)". Second, in the sentence of "who + weizhe(谓者)", "weizhe(谓者)" is the judgment predicate of the same subject-predicate structure. Third, the "who" is the subject of the judgment sentence, and "weizhe(谓者)" is the predicate of the judgment sentence. Fourth, this "zhe"(者) has the same grammatical meaning as the "zhe"(者) of "weizhe(谓者)", and does not express the questioning tone. Fifth, the questioning tone of the "who + weizhe(谓者)" sentence pattern is brought about by the interrogative pronouns and intonation [2]. We believe that the latter's view is more credible.

Regarding the nature of "ze" (则) and "qi" (其) at the end of the interrogative sentence, In Si Maqian's "A Reply to Ren
An", "Zhong Ziqi died, and Bo Ya would never play the musical instrument." Wei Peiquan regards this "ze" (则) as "language auxiliary", and regards "hezai" (何哉) and "heye" (何也) as the same grammatical form [18]. He Leshi points out that in the handed-down literature, questioning modal particle of "ze" is often used in conjunction with the question word "he"(何) to form interrogative sentence [14]. Zhang Yujin also points out that "ze"(则) has not been seen in the unearthed literature of the Warring States [6]. At the end of the interrogative sentence, "Wei Peiquan" regards "qi" of "he qi" as "demonstrative pronoun [18]. It is obviously not appropriate. The Institute of Language Studies of the Chinese Academy of Social Sciences considers that it is both the auxiliary word and the interrogative modal particle [20]. He Le Shi [14] and Zhang Yujin [6] all think that it can be regarded as an interrogative modal particle, which can be translated as "ne"(呢). Therefore, it is credible to regard the two words "ze"(则) and "qi"(其) at the end of the interrogative sentence as "interrogative modal particles".

Finally, we can also see some works on Chinese history. That is, the study involves the interrogative modal particles in the Chinese language of the Warring States, such as Chen Shuncheng's "investigation on the interrogative modal particle "ye"( 邪) and "ye"( 耶) [21] and Li Xiaojun's "Derivation and Evolution of Modal Particles from Pre-Qin dynasty to Tang dynasty and Five Dynasties [22] and so on. Similar arguments are more common. Therefore, the author wouldn't make the description.

\section{CONCLUSION}

At present, there are still limitations and prospects for the study of interrogative modal particles in unearthed and handed-down literature of the warring states.

First, the writings on the history of grammar have summarized the interrogative modal particles in term of lexical or semantic modal particles. They have not make the explanation on how the interrogative modal words evolving into other modalities in depth. Especially, the selection of interrogative tone is not described in detail.

Secondly, some scholars have made great efforts in the description of interrogative modal particles in the unearthed literature of the Warring States and pre-Qin dynasty. The corpus used is still limited to a part of the unearthed literature as the research object. The ancient books of the Warring States in the Han Dynasty (Such as, "Laozi" in Western Han Dynasty in Peking University, "Master Sun's Art of War" Yinqueshan Han Bamboo, etc.) and the interrogative modal particles in the literature of the Warring States have not been studied.

Third, traditional grammar scholars tend to use several common ancient books of the Warring States as the description of the Warring States Chinese or the pre-Qin Chinese, and do not combine the comprehensive unearthed literature of the Warring States as the basic corpus. Therefore, these scholars discriminate and analyze the similarities and differences between the interrogative words. The conclusion is likely to be incomplete or incorrect. 
In summary, the author has concluded the scholars' research on the interrogative modal words in the unearthed and handed-down literature of the Warring States. (1) There are many studies on the handed-down literature, and the research corpus can be combined with the unearthed literature. (2) The scope of the research corpus is still very narrow. It is only satisfied with several common ancient books of the Warring States Period. It just uses the unearthed literature of the Warring States as the research corpus. It is not aware of the ideas from the unearthed materials and the handed-down materials as the basic corpus. (3) The research perspective can be combined with contemporary linguistics, especially pragmatics, semantics and other theories to study the Chinese interrogative modal particles in the Warring States Period. In view of the above reasons, we know that the research on this topic is very urgent.

\section{ACKNOWLEDGEMENT}

This article is one of preliminary research results of the Key Project of 2017 National Social Science Fund, "Database Construction on Unearthed Document Translation of the Warring States" (Project No. 17AYY014). In the process of writing, the author received the careful guidance of Zhang Yujin, a professor at the School of Literature of South China Normal University.

\section{REFERENCES}

[1] He Linyi. General Theory of Words of the Warring States (scheduled) $[\mathrm{M}]$. Shanghai: Shanghai Ancient Books Publishing House, 2017: 31-41. 何琳仪.战国文字通论（订补） $[\mathrm{M}]$.上海:上海古籍出版 社, 2017:31-41.

[2] Zhang Yujin. Study on the lexical words in the unearthed literature of the warring States [M]. Beijing: People's Publishing House, 2011: 29-40, 522-632, 612-613, 522-523, 527-528, 529, 224-225, 450- 480. 张玉金. 出土战国文献虚词研究 [M]. 北京: 人民出版社, 2011:2940、522-632、612-613、522-523、527-528、529、224-225、450480 .

[3] Hua Jianguang. Study on the modal particle in handed-down documents of the Warring States[M]. Beijing: Guangming Daily Press, 2013: 15-16, 7-8, 102-146, 122-128. 华建光.战国传世文献语 气词研究 $[\mathrm{M}]$. 北京:光明日报出版社,2013:15-16、7-8、102-146、 122-128.

[4] Qi Huyang. Modal Particles and Modality System [M]. Hefei: Anhui Education Press, 2002: 21, 135. 齐沪扬. 语气词与语气系统[M].合 肥：安徽教育出版社,2002: 21、135.

[5] Lu Jianming, Shen Yang. Fifteenth Lecture on Chinese and Chinese Studies (2nd Edition) [M]. Beijing: Peking University Press, 2016: 18-31. 陆俭明、沈阳.汉语和汉语研究十五讲（第 2版）[M].北 京: 北京大学出版社,2016:18-31.

[6] Zhang Yujin. Research on the development of virtual words in the literature of pre-Qin Dynasty [M]. Guangzhou: Ji'nan University Press, 2016:211-251, 239, 211-251, 294-297, 239-242, 246-247, 251, 295 . 张玉金. 出土先秦文献虚词发展研究 $[\mathrm{M}]$. 广州: 暨南大学出 版社, 2016:211-251、239、211-251、294-297、239-242、246247、251、295.

[7] Shi Yuzhi. Conceptual Basis of Grammar [M]. Shanghai: Shanghai Foreign Language Education Press, 2006: 220-222. 石毓智.语法的 概念基础 $[\mathrm{M}]$.上海: 上海外语教育出版社,2006:220-222.

[8] Zhang Zhenzhen. The modal particle in the unearthed texts of the Warring States[D]. Master's thesis of Sun Yat-Sen University, 2016. 张珍珍. 出土战国文字资料中的语气词 [D]. 中山大学硕士学位论 文,2016.
[9] Cheng Wenwen. Research on the virtual words of Jianbo medical books [D]. Doctoral dissertation of Southwest University, 2016. 程文 文.简帛医书虚词研究[D].西南大学博士学位论文,2016.

[10] Zhang Zhenlin. Modal Particles in pre-Qin Ancient Writing Materials [J]. Ancient Chinese Studies (Vol. 7). Beijing: Zhonghua Book Company, 1982: 93-104. 张振林. 先秦古文字材料中的语气词 [J].古 文字研究(第 7辑).北京: 中华书局,1982:93-104.

[11] Chen Yongzheng. Modal Particles in the Inscriptions on the Western Zhou and Bronze Inscriptions of Spring and Autumn period [J]. Ancient Chinese Studies (19th Series). Beijing: Zhonghua Book Company, 1992: 565-578. 陈永正.西周春秋铜器铭文中的语气词 [J].古文字研究(第 19 辑).北京: 中华书局,1992:565-578.

[12] Wang Li. Ancient Chinese [M]. Beijing: Zhonghua Book Company, 1999: 268-281，280-281. 王力.古代汉语 [M]. 北京: 中华书 局,1999:268-281、280-281.

[13] Wang Kezhong. Investigation on the Word "yu"(与) in the pre-Qin Dynasty[J]. Proceedings of Ancient Chinese Studies 2. Beijing: Beijing Publishing House, 1984: 139.

[14] He Leshi. Ancient Chinese Dictionary of Function Words [M] Beijing: Language Publishing House, 2006: 551-553, 587, 582, 300 . 何乐士.古代汉语虚词词典[M].北京: 语文出版社,2006:551-553、 587、582、300.

[15] Hong Bo. Three-dimensional Ancient Chinese Course [M]. Beijing. Higher Education Press, 2005: 186-187. 洪波.立体化古代汉语教程 [M].北京: 高等教育出版社,2005:186-187.

[16] Zhu Yunshen. Two Syntaxes Related to "Ruo"(若) [J]. Linguistics Communication (No. 6), 1982: 177. 朱运申.两个跟“若”有关的句法 [J].语言学通讯(第 6 期),1982: 177.

[17] Xu Futing. Discussion on the "Wei"(为) at the End of Interrogative Sentences: "Why"(何以...为) [J]. Chinese Language (No. 5), 1980. 徐福汀.关于疑问句尾“为”的讨论:“何以...为”试析 [J].中国语文(第 5 期), 1980 .

[18] Wei Peiquan. Research on Pronouns in the Han and Wei Dynasties [M]. Taipei: Institute of Linguistics, Academia Sinica, 2004. 魏培泉. 汉魏六朝称代词研究 $[\mathrm{M}]$. 台北: 中央研究院语言学研究所,2004.

[19] Fang Youguo. Research on Ancient Chinese Grammar [M]. Chengdu: Bashu Shushe, 2002:122. 方有国.上古汉语语法研究[M].成都: 巴 蜀书社, 2002: 122 .

[20] Department of Ancient Chinese Studies, Institute of Linguistics, Chinese Academy of Social Sciences. Dictionary of Ancient Chinese Function Words. Beijing: The Commercial Press, 1999: 408. 中国社 会科学院语言研究所古代汉语研究室.古代汉语虚词词典.北京: 商务印书馆, 1999:408

[21] Chen Shuncheng. Investigation of the interrogative modal particle "ye"(邪) and "ye"(耶) [J]. Ancient Chinese Studies (No. 4), 2011. 陈 顺成. 疑问语气词“邪”“耶”的历时考察 [J]. 古汉语研究 (第 4 期), 2011 .

[22] Li Xiaojun. The Derivation and Evolution of Modal Particles from pre-Qin Dynasty to Tang Dynasty and Five Dynasties. Beijing: Beijing Normal University Press, 2013. 李小军.先秦至唐五代语气 词的衍生与演变.北京: 北京师范大学出版社,2013. 